\title{
Printing for Central Authorities in the Early Modern Low Countries (15th-17th Centuries)
}

\author{
Renaud Adam
}

In August 1495, Archduke Philip the Handsome promulgated a new constitution for the County of Zeeland (Keure van Zeelandt in Dutch). ${ }^{1}$ In Antwerp Govaert Bac later printed the text. It was the first time that the central authorities of the Low Countries resorted to printing to disseminate its official acts. This case, and in particular the links between the Antwerp printer Govaert Bac and the Burgundian court in Brussels, provide the starting point for a broader study, exploring the relationship between the community of printers and the central government in the early modern Low Countries. This complex relationship has not yet been the subject of a detailed study. Until now, only the relationship between printers and local, provincial or religious authorities have attracted the attention of scholars. Investigations were notably conducted on the French-speaking part of the Low Countries and Antwerp. ${ }^{2}$ To fill this

1 Abbreviations: ARB = State Archives of Belgium, Brussels; в B = Ferdinand Vander Haeghen, Bibliotheca Belgica. Bibliographie générale des Pays-Bas (7 vols., Brussels: Culture et civilisations, 1964-1975); CPE = Spanish Private Council; NK = Wouter Nijhoff, Maria Elizabeth Kronenberg, Nederlandsche bibliographie van 1500 tot 1540 (3 vols., The Hague: M. Nijhoff, 1923-1971); PP = Léon Voet, The Plantin Press at Antwerp (1555-1589) (6 vols., Amsterdam: Van Hoeve, 1980-1983); USTC = Universal Short Title Catalogue (https://www.ustc.ac.uk). The author would like to thank Dr Susie Sutch (Berkeley, USA) and the editors of the volume for their remarks and comments.

2 Sébastien Afonso, 'L'imprimé officiel: enjeu et objet de rivalités entre imprimeurs dans les villes du sud des Pays-Bas méridionaux au XVII e siècle', in Renaud Adam etc. (eds.), Urban Networks and the Printing Trade in Early Modern Europe (15th-18th Century). Papers presented on 6 November 2009, at the CERL Seminar hosted by the Royal Library of Belgium (London: Consortium of European Research Libraries, 2010), pp. 53-76; Stijn Van Rossem, 'Book and the City. The Urban Networks of the Verdussen family (1585-1700)', in Adam, Urban Networks and the Printing Trade, pp. 39-52; Sébastien Afonso, Imprimeurs, société et réseaux dans les villes de langue romane des Pays-Bas méridionaux (1580-ca 1677) (Free University of Brussels, Unpublished $\mathrm{PhD}$ dissertation, 2015-2016). The relationship between authorities and printers in France and in the Dutch Republic was studied in two recent publications: see Xavier Prévost, Les premières lois imprimées. Études des actes royaux imprimés de Charles VIII à Henri II (1489-1559) (Paris: École des Chartes, 2018); Andrew Pettegree and Arthur der Weduwen, The Bookshop of the World. Making and Trading Books in the Dutch Golden Age (New Haven/ London: Yale University Press, 2019), pp. 195-216. 
historiographical gap, we have decided to study the individuals behind the printing of publications from central government and how the distribution of these documents was regulated. This survey is based on a cross-analysis of the archives of central institutions and the documents printed for them. This chapter will provide a better understanding of the socioeconomic consequences resulting from printing the law in early modern period and add reflection on the connection between print and power.

\section{The Beginnings: Printing the Law under the Reign of Philip the Handsome}

It took some time for the relationship between printers and central authorities to become official. The first official privilege was granted in 1531. To understand how this relationship has been built, we have to look for all the connections that brought printers and central government together. The first is certainly the new constitution for Zeeland mentioned in the introduction. It followed other charters previously issued by Florent the Tutor around 1257 , by Florent $\mathrm{V}$ of Holland in 1290, and by William III of Holland-Hainaut in 1328. The new charter was proclaimed in different towns in the province: Middelburg on 24 or 25 April 1496, Zierikzee on 28 April and Reimerswaal the following day. This law remained in force, with some amendments, until the annexation of Zeeland by France in $1795^{3}$

This legislative text was printed shortly after its promulgation by Govaert Bac in Antwerp in 64 sheets in quarto format. ${ }^{4}$ Three of the five surviving copies bear the autograph signatures of two commissioners who participated in its preparation. The Royal Library of Belgium has a copy with the following inscription on the last page: gecolla[tio]neert tegens die originael brieve $[n]$ bij Capelle [collated from the original letter by Capelle] (fol. 64r). ${ }^{5}$ Capelle was the councillor and master of requests Richard de La Chapelle, who entered the service of the Dukes of Burgundy in $1473 .{ }^{6}$ The two other copies in possession of the national library in The Hague and the British Library in London

3 Robert Fruin, De Keuren van Zeeland (The Hague: M. Nijhoff, 1920).

4 Keure van Zeeland ([Antwerp: Govaert Bac, ca. 1496-1497]), USTC 436385.

5 Royal Library of Belgium, Inc A 1.426.

6 Richard de La Chapelle was canon of St. Donatian's Cathedral in Bruges, dean of Our Lady in Veere and doctor of canon law. He began his administrative career as an ecclesiastical advisor to the Parliament of Mechelen (1473), before becoming master of requests (1477). He held this position until his death in 1511. See: Alida Johanna Maria Kerckhoffs-De Heij, De grote raad en zijn functionarissen. Biografieen van raadsheren (Universiteit van Amsterdam, 
also bear an identical formula. ${ }^{7}$ The only difference is that another ducal secretary signed them. These were signed by Jan van Coudenberghe, secretary of the Great Council in Mechelen since $1487 .{ }^{8}$ The two ducal secretaries conscientiously corrected the typographical errors. Coudenberghe was more meticulousness than Richard de La Chapelle. Collating the copies reveals that Chapelle overlooked mistakes.

The presence of the secretaries names was aimed at reinforcing the authority of the document, but also, and above all, at authenticating it. The formula gecollationeert tegens die originael brieven placed at the end of the book is an authentication formula used by the Chancellery of the Dukes of Burgundy. ${ }^{9}$ The use of handwritten signatures on printed documents to authenticate them was common at this time. For example, the copies of the indulgence in favour of the repair of the hospital of Santiago de Compostela, preached in 1497 by Alphonsus de Losa and printed by Dirk Martens, still bear traces of the ancient seal of the legate, as well as his autograph signature. ${ }^{10}$ The collation work also suggests that it was an order placed directly by the court and not a personal initiative of the printer.

The reason why Govaert Bac printed the Keure van Zeelandt can certainly be found in his links with the Confraternity of the Seven Sorrows, especially as one of its founders, Jan van Coudenberghe, directly participated in the revision of the text. The Confraternity of the Seven Sorrows of the Virgin Mary was established in $1492 .{ }^{11}$ It was placed under the patronage of young Philip the Handsome, and was largely supported by the entourage of the Archduke.

Unpublished PhD dissertation, 1980), p. 45; Céline Van Hoorebeeck, Livres et lectures des fonctionnaires des ducs de Bourgogne (ca 1420-1520) (Turnhout: Brepols, 2014), pp. 190-192. British Library, IA 49.951, fol. 64r; National Library of the Netherlands, $225 \mathrm{H} 42$, fol. 64r.

8 Jacob Fruytier, 'Coudenbergh (Jan de)', in Philipp Christiaan Molhuysen, Petrus Johannes Blok and Friedrich Karl Heinrich Kossmann (eds.), Nieuw Nederlandsch Biografisch Woordenboek (11 vols., Amsterdam: N. Israel, 1974), viI, pp. 333-334.

$9 \quad$ Pierre Cockshaw, Le personnel de la chancellerie de Bourgogne-Flandre sous les Ducs de Bourgogne de la Maison de Valois (1384-1477) (Heule-Kortrijk: UGA, 1982), pp. 162-163.

10 Royal Library of Belgium, Inc A 2.342; British Library, IA.50021; Bodleian Library, Arch. B b.5 (26/1); Bibliothèque Mazarine, Rés. 3439 Abis. Reference of the edition: Alphonsus de Losa, Indulgentia 1497 [ for the benefit of the confraternity of St James of Compostella] ([Antwerp: Dirk Martens, about 1497]), USTC 438703.

11 On this confraternity, see: Pérégrin-Marie Soulier, La confrérie de Notre-Dame des Sept Douleurs dans les Flandres 1491-1519 (Brussels: Pères Servites de Marie, [1912]); Susie Speakman Sutch and Anne-Laure Van Bruaene, 'The Seven Sorrows of the Virgin Mary: Devotional Communication and Politics in the Burgundian-Habsburg Low Countries (c. 1490-1520)', Journal of Ecclesiastical History, 61 (2010), pp. 252-278; Emily S. Thelen (ed.), The Seven Sorrows Confraternity of Brussels. Drama, Ceremony, and Art Patronage (16th-17th Centuries) (Turnhout: Brepols, 2015). 
Unlike many confraternities, the ambition of these men was to go beyond strictly religious concerns and to try to bring people together in emotional and spiritual communion with the Burgundian-Habsburg dynasty. Its final aim was to unite the people, something Maximilian of Austria never managed to achieve despite all his efforts. ${ }^{12}$ Beyond the image of the Virgin mourning the death of her son is the suffering of young Philip the Handsome who lost his mother, Mary.

Although no list of members of the Antwerp chapter has survived, two printers can nevertheless be associated with it: Gheraert Leeu and Govaert Bac. Leeu was the first printer to publish a text that dealt with the devotion to the Seven Sorrows. Around 1492, he printed a short treatise of 16 sheets entitled Van de seven droefheden ofte weeden Onze Lieve Vrouw, in octavo format. ${ }^{13}$ Was it a personal initiative testifying to his attachment to the brotherhood, evidence of a keen business sense, or, more simply, an order from the central authorities? A letter from Gheraert Leeu to Philip the Handsome, published shortly after the Leeu's death by Govaert Bac, provides part of the answer to this question. In his letter, Leeu humbly asks permission to print a missal as well as books of hours intended for the devotion to the Seven Sorrows. Prudently, he also suggested that he could submit the texts to the Archduke before printing them so that he and/or his close councillors could review them and correct them if necessary. ${ }^{14}$ The printer does not seem to have been directly commissioned by the Archduke's entourage, but rather to have offered his services as a collaborator. If Leeu's initiative was linked to his presence in a circle close to this devotion, it is, however, impossible to assert that he was a member of the confraternity.

The case of Govaert Bac seems clearer. The Confraternitas dolorum Beata Virginis Mariae, in which Leeu's letter was published, contains in its preface an epistle written by Bac dedicated to the whole dolorum Beatissime Virginis Marie confraternitas (fol. 2r-v). In this text, Bac describes the leading role played by Philip the Handsome in the diffusion of that devotion, as well as his own involvement. He affirmed that he had taken the task of printing this

12 Two centuries later, Marian worship was again instrumentalised by the Habsburg dynasty, which was struggling to maintain its control over the Spanish Low Countries, shaken by incessant wars and divided by local particularist demands. On this, see: Annick Delfosse, 'La Protectrice du Païs-Bas'. Stratégies politiques et figures de la Vierge dans les Pays-Bas espagnols (Turnhout: Brepols, 20o9). For Brussels, see: Renaud Adam, 'L'Histoire de Saint sacrement de Miracle d'Étienne Ydens (1605), œuvre de dévotion ou œuvre polémique ?', Revue Belge de Philologie et d'Histoire, 92 (2014), pp. 413-433.

13 Van de seven droefheden ofte weeden O.L.V (Antwerp: [Ghereart Leeu, between 30 April 1491-1492]), USTC 436052.

14 Confraternitas dolorum B.V.M. Officium de doloribus B.V.M. (Antwerp: Govaert Bac, [1493-1494]), USTC 436177, fol. 9v. 
Confraternitas dolorum Beata Virginis Mariae upon himself, with the agreement of the Archduke and of the brotherhood (fol. 2r).

The last publication in connection with Philip the Handsome was the account of the solemn funeral of the Archduke celebrated in Mechelen on 18 and 19 July 1507, written by Jean Lemaire de Belges. ${ }^{15}$ Willem Vorsterman published this text simultaneously in French and Dutch. This double publication highlights the official character of this story. ${ }^{16}$ The presence, following the description of the funeral, of a song celebrating the new treaty of peace and trade concluded with England in 1507 underlines the eminently political aspect of the initiative. Here, Jean Lemaire de Belges played the role of historiographer. ${ }^{17}$ The association of the two texts is far from accidental. Margaret of Austria thus benefitted from the moral guarantee of her brother for one of her first political acts as regent.

\section{Towards a More Active Government Policy: Printing the Law under Charles v}

Until 1512, the Habsburg authorities did not interfere in the regulation of the book market. ${ }^{18}$ The first intervention by the civil government resulted from a commercial dispute between the printer Claes de Grave and Henrick Eckert and his associates. This case concerned the printing of a prognostication written by the astrologer Jaspar Laet. Claes de Grave filed a complaint before

15 This text is a passage from a handwritten chronicle of the year 1507 written by Jean Lemaire de Belges. Only the part relating to Philip the Handsome's funeral was printed. On this subject, see: Anne Schoysman (ed.), Chronique de 1507 (Brussels: Royal Academy of Belgium, 2001).

16 Jean Lemaire de Belges, La pompe funeralle des obseques du feu roy dom Phelippes ([Antwerp: Willem Vorsterman, 1507]), ustc 26124; Jean Lemaire de Belges, Die funerallen ende deerlike triumphen oft pompen vander uutvaerden van wijle dom Philippus ([Antwerp: Willem Vorsterman], 1507), usTC 436747. The French version is edited by Jean Stecher (ed.), CEuvres de Jean Lemaire de Belges (4 vols., Louvain: Lefever, 1882-1885), Iv, pp. $243-266$.

17 The text is edited in CEuvres de Jean Lemaire de Belges, IV, pp. 267-268.

18 On the regulation of the profession of printer in the beginnings of the typographical era, see Renaud Adam, 'The Profession of Printer in the Southern Netherlands before the Reformation. Considerations on Professional, Religious and State Legislations', in Wim François, Violet Soen and Dries Vanysacker (eds.), Censorship and Catholic Reform in the Early Modern Low Countries (Turnhout: Brepols, 2017), pp. 13-25. A short history of the regulation of the book trade during the 'long sixteenth century' can be found in Paul Arblaster, From Ghent to Aix. How They Brought the News in the Habsburg Netherlands, 1550-1700 (Leiden/Boston: Brill, 2014), pp. 21-28. 
an Antwerp court regarding Laet's desire to sell his text to various printers. Following the judgement of 7 November 1511, Claes de Grave obtained the rights of reproduction for one month. The judges decided that the astrologer had the right to choose his printer, but that he should return the sum of 2o Rhine guilders he received from Eckert and his associates as payment for the book. De Grave received the sum of 12 Rhine guilders as a compensation from Laet. ${ }^{19}$ Around Christmas, after a period of 30 days imposed by the court, Henrick Eckert hired some colleagues and worked with four or five presses and 15 or 16 apprentices. They intended to publish Laet's prognostication as soon as possible. Eckert hoped to overtake Claes de Grave. Forewarned, Claes de Grave complained to the Council of Brabant, the sovereign court of the duchy. On 5 January 1512, the Council of Brabant decided to allow Claes de Grave to print all books not yet published in the duchy, and prohibited any of his colleagues from reprinting these books during six years. ${ }^{20}$ This was the first case of a privilege being granted to a printer by the civil government in the Low Countries. ${ }^{21}$

Although the Council of Brabant was a sovereign court, it was still under the scrutiny of Habsburg ruler. Therefore, even if printers asked for protection from the Council, the central government still maintained some rights of inspection. When the Duchy of Brabant came under the domination of the Dukes of Burgundy, and later of the Habsburg dynasty, they managed to keep a certain degree of autonomy. So, before granting any privilege, the Council of Brabant made sure to take advice and deliberation from the regent, Margaret of Austria. ${ }^{22}$ After 1531, printers also had the opportunity to address a petition

19 Prosper Verheyden, 'De Antwerpsche boekdrukker Henrick Eckert van Homberch alias Butzbach, 'Bosbas', en zijn 'herdoopte' weduwe', De Gulden Passer, 16-17 (1938-1939), pp. 103-121. The Niedersächsische Staats- und Universitätsbibliothek has several fragments of Laet's prognostication for the year 1512 attributed to Willem Vorsterman: Jaspar Laet, Pronostication de l'an 1512 ([Antwerpen: Michiel Hillen, ca. 1511]), not recorded in USTC; see NK 4514. Is it one of the copies of the controversial almanac? On this topic see: Wytze \& Lotte Hellinga, 'Eclipses and Early Printing', Gutenberg-Jahrbuch, 46 (1971), pp. 99-102.

20 The document is edited in Verheyden, 'De Antwerpsche boekdrukker Henrick Eckert', pp. 104-106. See also : Alphonse Wauters, 'Histoire des livres. Documents pour servir à l'histoire de l'imprimerie dans l'ancien Brabant', Bulletin du bibliophile belge, 12 (1856), p. 74; Prosper Verheyden, 'Drukkersoctrooien in de $16^{\mathrm{e}}$ eeuw', Tijdschrift voor Boek - en Bibliotheekwezen, 8 (1910), pp. 208-209, nr. 1; Lode Van den Branden, 'Drukoctrooien toegekend door de Raad van Brabant tot 160o', De Gulden Passer, 68 (1990), p. 13, nr. 1.

21 For a European overview, see Edwige Keller-Rahbé (ed.), Privilèges de librairie en France et en Europe $X V I^{e}-X V I I^{e}$ siècles (Paris: Classiques Garnier, 2017).

22 Thomas van der Noot's privilege (1512) mentioned that the authorities took advice from "notre tres cher et tresaimee fille de Monseigneur Empereur dame et tante de Monseigneur Charles larchiduchesse Marguerite d'Autriche, régente des Pays-Bas" [our dearest and 
to the Privy Council to obtain protection beyond the limits of Brabant: the central institution of government over the whole Low Countries, including the Duchy of Brabant. ${ }^{23}$

The government policy towards printers became more and more restrictive after the rise of the Reformation. The first repressive edict to combat heresy was published on 28 September 1520, preceding even the Edict of Worms. This was followed by a new edict in March 1521, which prohibited the printing, sale, purchase, storage and reading of Lutheran books under threat of confiscation of all property and of other unspecified punishments. Less than two months later, on 26 May, Charles v signed the famous Edict of Worms, which extended the ban to books attacking the Roman Church, the Pope and the University of Louvain. As a corollary, the Council of Brabant stopped granting general monopolies to printers and restricted itself to granting privileges for specific editions. The authorities quickly realised that the system of granting privileges could be a useful weapon to support its struggle against heresy and subversive forces of all forms. This is why, by the edict of 14 October 1529, they forced each printer to submit all texts for ecclesiastical and official examination. ${ }^{24}$

The first privilege granted by the central authorities for printing its own ordinances goes back to $3_{1}$ October 1531, when Michiel Hillen obtained permission to print ordinances from 'His Imperial Majesty', excluding all other printers for six months. ${ }^{25}$ This concession coincided with the proclamation of a new edict against 'Lutherans and other disapproved sects', dated 7 October $1531 .{ }^{26}$ Hillen printed this ordinance simultaneously in French and in Dutch on 31 November 1531 in collaboration with his colleague Willem Vorsterman. The content of the privilege states that every violator would be fined 100 carolus guilders.

beloved lord Emperor's daughter and lord Charles' aunt the archduchess Margaret of Austria, regent of the Low Countries] (ARB, Chamber of Accounts, 635, fol. 213r).

23 Michel Baelde, 'De toekenning van drukkersoctrooien door de Geheime Raad in de zestiende eeuw', De Gulden Passer, 40 (1962), pp. 19-56.

24 André Puttemans, La censure dans les Pays-Bas autrichiens (Brussels: Georges Van Campenhout, 1935), pp. 13-22; Jeroom Machiels, Privilège, censure et index dans les PaysBas méridionaux jusqu'au début du XVIII e siècle (Brussels: State Archives of Belgium, 1997), pp. 59-113; Aline Goosens, Les inquisitions modernes dans les Pays-Bas méridionaux (1520-1633) (2 vols., Brussels: Éditions de l'Université Libre de Bruxelles, 1997-1998), I, pp. 47-112; Jochen A. Fühner, Die Kirchen- und die antireformatorische Religionspolitik Kaiser Karls V. in den siebzehn Provinzen der Niederlande 1515-1555 (Leiden: Brill, 2004). Wauters, 'Histoire des livres', p. 75; Van den Branden, 'Drukoctrooien', p. 16, nr. 20.

26 Charles v, Ordinantien ende statuten, 07.10 .1531 op te extirperen ende te verdriven de Lutheraensche ende andere ghereprobeerde secten (Antwerp: Willem Vorsterman \& Michiel Hillen, 1531), UsTC 437594. 
Interesting to note is that such a privilege was not granted for the printing of earlier edicts on heresy. The Edict of Worms, printed in June 1521 by Dirk Martens in Louvain and by Vorsterman in Antwerp, doesn't bear any mention of a privilege. ${ }^{27}$ The need to react quickly to the imperial condemnation of Luther at the diet of Worms could certainly explain this. It was the papal legate Girolamo Aleandro, who had just returned from Worms, who contacted these printers to print the text. ${ }^{28}$

Less than ten years later, on 7 October 1540, the Brussels bookseller Marck Martens was granted a privilege for one year to print all the ordinances regarding heresy. ${ }^{29}$ As for Hillen, the granting of this privilege followed the promulgation of a new edict against the heterodoxy by the Emperor on 22 September 1540. The proximity to the court, established in Brussels in 1531 by Mary of Hungary, can certainly explain the choice to print there. Martens received a new privilege on 2 December 1541 to print all the new ordinances (om te mogen prenten de nyeuwe ordinnancien). ${ }^{30}$ However, after this date there are no further references to him in surviving documents.

A few months later, the authorities decided to create an exception for ordinances dealing with economic matters, especially those regarding the reproduction of coins. The bookseller Victor de Dayn from Ghent was granted a privilege for reproducing 'books relating to markets, measures and weights'

27 Charles v, Edictum imperial ex convent Wormatiae habito 1521 contra Martinum Lutherum ([Leuven: Dirk Martens, 1521), NK 3298; not recorded in UsTC; Charles v, Edictum imperial ex convent Wormatiae habito 1521 contra Martinum Lutherum (Antwerp: Willem Vorsterman, 1521), USTC 437163 .

28 Aleandro encountered some difficulties with Martens. The printer seemed to be reluctant to print Luther's condemnation. On this, see: Paul Fredericq, Corpus documentorum inquisitionis haereticae pravitatis Neerlandicae. Verzameling van stukken betreffende de pauselijke en bisschoppelijke inquisitie in de Nederlanden (5 vols., Ghent/The Hague: J. Vuylsteke /M. Nijhoff, 1889-19o2), v, pp. 400-401; Renaud Adam and Alexandre Vanautgaerden, Thierry Martens et la figure de l'imprimeur humaniste (une nouvelle biographie) (Turnhout: Brepols, 2009), pp. 124-125.

29 Wauters, 'Histoire des livres', p. 76; Van den Branden, 'Drukoctrooien', p. 19, nr. 34. Marck Martens never owned his own printing house and he mainly collaborated with Antwerp's printer Jacob van Liestvelt. He was accused of selling heretical books and having printed, in collaboration with Liesvelt, a bull from Paul III in Flemish and French without authorization (1536). See: Prosper Verheyden, 'Verhooren van Mark Martens en van Jacob van Liesveldt (1536)', Tijdschrift voor boek - en bibliothekenwezen, 4 (19o6), pp. 245-261; Auguste Vincent, 'Linterrogatoire de Marc Martens et Jacques van Liesveldt', Revue des bibliothèques et archives de Belgique, 7 (1909), pp. 40-44; Anne Rouzet, Dictionnaires des imprimeurs, libraires et éditeurs des $X V^{e}$ et $X V I^{e}$ siècles dans les limites actuelles de la Belgique (Nieuwkoop: De Graaf, 1975), pp. 128-129, 139-140.

Wauters, 'Histoire des livres', p. 76; Van den Branden, 'Drukoctrooien', p. 2o, nr. 41. 
on 23 March 1542. ${ }^{31}$ The next year, on 22 October 1543, Josse Lambrecht, who acted as a Dayn's printer, received the same authorisation. ${ }^{32}$ The need to have appropriate material - woodcuts reproducing coins faithfully - certainly explains why the authorities decided to entrust the reproduction of these documents to a single printer. It was easier for the government to give that kind of monopoly to one person than to have to change every year and then have to check the press equipment for every new printer.

On 30 June 1546, Charles v promulgated a new edict of censorship that introduced the obligation for printers to place the content of the privilege granted by the authorities at the beginning of their books. This is very valuable for historians of the book, since the content of each petition is mentioned in its corresponding privilege. The text of the privilege granted to Servaes van Sassen for printing the edict of 1546 - in Latin, Dutch and French - tells us that he applied for the privilege and that he assumed the costs of printing and selling the edict to obtain it. ${ }^{33}$ Personal involvement and economic justification are two arguments that would be used thereafter by printers in almost all petitions made to the central authorities.

\section{Towards Monopolies: Printing the Law under Philip I I of Spain}

The reign of Philip II was marked by the creation of the semi-permanent position of official court printer and the appearance of two new titles: King's Printer (typographus regius) and chief printer of the King (architypographus/ prototypographus regius). ${ }^{34}$ Willem Silvius, a native of 's-Hertogenbosch, was the first printer of the Low Countries to receive the title of King's Printer. ${ }^{35}$ After obtaining his Master of Arts degree on 31 March $155^{8}$ in Louvain, Silvius

31 The original reads: "volumen aengaende den mercten maeten ende gewichten". See Van den Branden, 'Drukoctrooien', p. 20, nr. 44.

32 Van den Branden, 'Drukoctrooien', p. 21, nr. 51.

33 Published in three languages: Charles v, Edictum promulgatum anno M.D.XLVI. Catalogus librorum reprobatorum/ Mandement donne et publie en l'an 1546. Avecq catalogue, intitulation ou declaration des livres reprouvez/Mandement int jaer XLVI met dintitulatie ende declaratie vanden gereprobeerde boecken (Louvain: Servais de Sassen, 1546), USTC 1309o, 406206, 408488.

34 On the title of King's Printer in France and in England, see: Elizabeth Armstrong, Robert Estienne, Royal Printer. An Historical Study on the Elder Stephanus ([Appleford]: Sutton Courtenay, 1986), pp. 117-161.

35 On Silvius, see: Rouzet, Dictionnaires des imprimeurs, p. 201-203; Paul Valkema Blouw, 'Willem Silvius's remarkable start, 1559-62', Quaerendo, 20:3 (199o), pp. 167-206; Pettegree and der Weduwen, The Bookshop of the World, pp. 197-198. 
settled in Antwerp where he received a printer's license on 6 May $1558 .{ }^{36} \mathrm{He}$ must have opened his bookshop during the winter of 1559/6o. The first publications under his name (an official publication in French and two scholarly works) were printed in 156o and were accompanied by a formula indicating his status as an official typographer: Typographus Regii or Imprimeur du Roy. ${ }^{37} \mathrm{His}$ appointment by the government was a great success for him, occurring right at the beginning of his career. This nomination of such a recently established printer is rather exceptional. There were at that time candidates with better and older rights to the appointment of King's Printer.

Sylvius obtained his title thanks to the printing of one book - an edition of the Statutes of the Order of the Golden Fleece - and his good relations with the court. ${ }^{38}$ On 26 July 1559, Joachim Hopperus, member of the Great Council of Mechelen, sent a report to Viglius ab Aytta, president of the Council of State, in which he asked for his old friend Silvius to be appointed typographer royal on account of the typographical quality of the production of the Statutes of the Order. ${ }^{39}$ The appointment must have taken place before 8 October 1559, when Christopher Plantin opened an account to 'master Willem Silvius Printer of the King. 40

The post of Royal Printer was not a direct source of income for printers who held it. Indeed, shortly after the nomination of Silvius, Michiel van Hamont, from Brussels, was appointed sworn printer of the King, and received an effective monopoly on all royal ordinances. Unfortunately, the document ratifying Hamont's appointment has not been preserved and as a result we do

36 Edmond H.J. Reusens, 'Promotions de la faculté des arts de l'université de Louvain, 14281797', Analectes pour servir à l'histoire ecclésiastique, 3 (1866), p. 467; Van den Branden, 'Drukoctrooien', p. 40, nr. 186.

37 Philip II, Ordonnances, statuts, stil et maniere de proceder (Antwerp: Willem Silvius, 1560), USTC 38593; Theodor Poelmann, Studio accuratissime castigatus, \& adnotationibus variis, asterisco designatis, illustratus (Antwerp: Willem Silvius, 156o), USTC 404352; Johannes Voerthusius, Phoenicis sive consecrationis Augustae liber unus (Antwerp: Willem Silvius, 1560), USTC 441291.

38 The text was printed in Latin and French: Constitutiones clarissimi ordinis velleris aurei trans. by Nicolaus Grudius (Antwerp: Willem Silvius, 1559), USTC 404310; Les ordonnances de l'ordre de la toison d'or (Antwerp: Willem Silvius, 1559), ustc 6115o; recorded in USTC as [Antwerp: Christophe Plantin, 1560]).

39 Maurice Van Durme (ed.), Supplément à la correspondance de Christophe Plantin (Antwerp: De Nederlandsche Boekhandel, 1955), p. 11, nr 1. Hopperus and Sylvius must have met at the University of Louvain. Silvius registered to university on 3 February $155^{\circ}$ and Hopperus obtained his doctorate on 27 Augustus 1553, see Charles Rablebeek, 'Hopper (Joachim)', in Biographie nationale [de Belgique] (43 vols., Brussels: Bruylant, 1866-1986), IX, pp. 466-469.

Quoted by Valkema Blouw, 'Willem Silvius's remarkable start, 1559-62', p. 172. 
not know exactly why he was chosen. Maybe due to his proximity to the court in Brussels? Anyway, the function would be created at the beginning of 1560 , because Silvius received a derogation from the privilege of Hamont to 'print some ordinances' on 18 February $1560 .{ }^{41}$ For Silvius, the Royal Printer post must have been important for his reputation as a publisher, because this implied a recognition of his abilities. He continued to call himself royal typographer until he left to Leiden in 1579.

On 2 March 1568, Silvius was arrested on suspicion of Protestant sympathies and for his involvement in the Iconoclastic Fury of August 1566. He was released a month later, on 26 April, after paying a bail of 2,ooo carolus guilders. On 16 July, he was acquitted. ${ }^{42}$ At the same time, Plantin wrote a letter to Jean Moffin, Philip II's confessor, in which he explained that Silvius printed the Statutes of the Order of the Golden Fleece in the Officina Plantiniana while he was in Paris. ${ }^{43} \mathrm{He}$ also mentions that cardinal Granvelle first refused to give the title to Silvius because the King wanted to appoint Plantin. After that, Silvius would have come beg Plantin to obtain the coveted title. Scholars had previously accepted Plantin's statements as true, but recent work has shown this not to be the case. ${ }^{44}$ According to Paul Valkema Blouw, in 1559 Plantin had no relation with the Court in Brussels. Moreover, it would be surprising if Plantin, a born Frenchman, had been considered for an appointment as Printer of the King immediately after the conclusion of the peace of CateauCambrésis (3 April 1559), which marked the end of the 65-year struggle between France and Spain for the control of Italy. ${ }^{45}$ Plantin certainly must have wanted to distance himself from his colleague. After he was arrested and released, Silvius could continue to call himself Royal Printer, but he had long since lost the post.

41 Van den Branden, 'Drukoctrooien', p. 41, nr. 194.

42 Rouzet, Dictionnaires des imprimeurs, p. 201; Valkema Blouw, 'Willem Silvius's remarkable start, 1559-62', p. 169; Guido Marnef, 'Repressie en censuur in het Antwerps boekbedrijf, 1567-1576', De zeventiende eeuw, 8 (1992), pp. 222-223.

43 The letter, undated, is edited in: Max Rooses \& Jan Denucé (ed.), Correspondance de Christophe Plantin (9 vols., Antwerp: J.E. Buschman/Ghent: A. Hoste, 1883 [I]; Ghent: A. Hoste/The Hague: M. Nijhoff, 1885 [II]; Antwerp: De Nederlandsche Boekhandel/The Hague: M. Nijhoff, 1911-1918 [III-IX]), I. 256-257.

44 On this debate, see: Henry de la Fontaine Verway, 'Hoe werd Silvius koninklijk drukker?', Het Boek, 26 (1940-1942), p. 222; Colin Clair, 'Willem Silvius', The Library, 14 (1959), pp. 192-205; Valkema Blouw, 'Willem Silvius's remarkable start, 1559-62', pp. 171-183.

45 On this peace, see: Bertrand Haan, Une paix pour l'éternité. La négociation du traité du Cateau-Cambrésis (Madrid: Casa de Velázquez, 2010). 
The most lucrative position for a printer was held by Michiel van Hamont, as 'sworn printer of his Majesty for the placards and ordinances' ${ }^{46}$ He settled in Brussels around 1557, and his presses ran until 1581 ; he died in $1585 .{ }^{47}$ His book production was negligible, comprising less than 15 titles, mainly in Dutch. These included texts by the abbot Louis de Blois and his Dutch translator Josse Schellinck, the schoolmaster Noël de Berlaimont, the historian Nicolaus Mameranus and the Franciscan Frans Vervoort. In addition to these texts, Hamont printed almost two hundred edicts and ordinances on behalf of the central government, in both Dutch and French. The privilege given to Hamont on 3 February 1557, which to allowed him to print books, specifies that he was also authorised to publish woodcuts and engravings. ${ }^{48}$ Plantin confirmed this twenty years later, in the certificate renewing Hamont's licence to exercise his profession dated 15 July 1570 . He described him with these words:

expert ... in the art of printing ... is able to speak Latin, Spanish, German and Flemish well but no French, is able to carve wood engravings, and knows how to correct in forms and printed proofs, and is able to design images and other things. ${ }^{49}$

Plantin thus informs us that Hamont was also able to speak Latin, Spanish, German and Dutch, but not French. Hamont had to share his monopoly with

46 This title was found in a petition to obtain the succession of Hamont: ARB, CPE, 1276, 9. The original reads: "Imprimeur Jure des placcarts et ordinances de sa Majeste".

47 Léopold Le Clercq, 'Michel van Hamont, 'figuersnijder' te Brussel (1556-1585)', De Gulden Passer, 21 (1945), pp. 113-118; Rouzet, Dictionnaire des imprimeurs, pp. 87-88; Edmond Roobaert, 'Michiel van Hamont. Hellebaardier van de keizer, rederijker en drukker van de koninklijke ordonnanties en plakkaten', in Frank Daelemans and Ann Kelders (eds.), Miscellanea in memoriam Pierre Cockshaw (1938-2008) (2 vols., Brussels: Archives et Bibliothèques de Belgique, 2009), II, pp. 465-485; Renaud Adam, 'Spanish Books in Michiel van Hamont's Bookshop (1569): a Case Study of the Distribution of Spanish Books in Sixteenth-Century Brussels', Quarendo, 48:4 (2018), pp. 30o-316 and Renaud Adam, 'Men and books under watch: the Brussels' Book Market in the Mid-Sixteenth Century Through the Inquisitorial Archives', in Shanti Graheli (ed.), Buying and Selling: The Early Book Trade and the International Marketplace (Leiden/Chicago: Brill, 2019), pp. 303-321.

48 Van den Branden, 'Drukoctrooien', p. 39, nr. 184.

49 The original reads: "expert ... audit estat d'imprimerie ... entendant for bien latin, espagnol, haut alleman et flameng et aucunnement François et taille aussi figures en bois, et sçait corriger sur le plomb et espreuves, et patronner figures et autres choses", Philippe Rombouts, Certificats délivrés aux imprimeurs des Pays-Bas par Christophe Plantin et autres documents se rapportant à la charge du Prototypographe (Antwerp/Ghent: J.E. Buschmann/ A. Hoste, 1881), p. 5. The license was approved two days later by the authorities. Van den Branden, 'Drukoctrooien', p. 50, nr. 254. 
Plantin after his appointment as chief printer of the King (architypographus/ prototypographus regius) to the Low Countries by Philipp II on 19 May 1570:

We have decreed and do hereby decree ... that there shall be created and instituted a prototypographus or first printer who shall have oversight of the trade of printing; who shall have authority to examine and approve the masters and workmen of this craft in our lands from this side onwards and to grant each and every one of them letters of competence according to their ability; for which further letters of confirmation and approval shall thereafter be requested from us or from our aforesaid Lieutenant and Governor-General in our dominions from this side onwards. 50

Plantin was charged with examining the professional skills and orthodoxy of men involved in printing trade (master printers, craftsmen, and apprentices). ${ }^{51}$ However, Plantin tried to relieve himself of this burden, arguing that he did not practice Dutch well enough to carry out the interrogations, but no one could contradict the King's orders. Two months after his appointment, on 28 June 1570, he took the oath before the president of the Private Council at Brussels, Charles de Tisnacq. ${ }^{2}$

The decision made by Philip II was a response to the lack of thorough supervision of the printing trade in the context of the struggle against heresy. The king wanted to control the entrance to the printing trade and to exclude the black sheep: both those who did not know the trades of the book and those suspected on religious or moral grounds.

As the chief printer of the King, Plantin did not receive money. He tried to obtain tax reductions, particularly on wine and beer, but to no avail. ${ }^{53}$ Despite this, he received official orders from the government, such as the 1570

$5^{\circ} \quad$ Quoted by Léon Voet, The Golden Compasses. A History and Evaluation of the Printing and Publishing Activities of the 'Officina Plantiniana' at Antwerp (2 vols., Amsterdam/London/ New York: Vangendt, 1969-1972), I, p. 70.

$5^{1} \quad$ The certificates still kept are edited in: Rombouts, Certificats. For more detail on these examinations, see: Voet, The Golden Compasses, I, pp. 70-72.

52 The revolt of the Low Countries in 1576 left Plantin with the title and no authority on the community of printers. After the Pacification of Ghent, signed on 8 November 1576, and the restoration of Spanish rule, Philip II neglected to make his decree effective again. Plantin continued to be called 'king's printer', but without power. His son-in-law Jan Moretus did not inherit the title. Balthasar Moretus was granted the title of 'architypographus regius' in about 1639 (Voet, The Golden Compasses, I, p. 73).

Correspondance de Christophe Plantin, II, p. 153, nr. 238. 
and 1571 indexes and, from 1570, royal ordinances. ${ }^{54}$ For Léon Voet, this 'must be regarded as not much the result of his new status, as of his good relations with the Spanish authorities. ${ }^{55}$ As early as 1570 , Plantin began to make joint petitions with Michiel van Hamont for privileges on the printing and distribution of ordinances. The first petition concerned the ordinance of criminal law of $1570 .{ }^{56}$ The two printers received a privilege for a period of six years on 6 September 1570. Offenders would be fined 100 carolus guilders per copy and would see their editions confiscated. ${ }^{57}$

On 6 November 1574, Plantin obtained a special appointment for the printing of currency edicts. ${ }^{58}$ This privilege was previously in possession of Hendrik I vanden Keer, active in Ghent from 1556 to 158 o, who conceded it to Plantin. ${ }^{59}$ Hendrik I vanden Keer had obtained this privilege in 1557. The previous holder was Josse Lambrechts. Before granting this monopoly to Hendrik I vanden Keer, the Chamber of Accounts was consulted and gave a favourable opinion on 22 May $1557 .^{60}$ In his petition to the Privy Council, Hendrik I vanden Keer argued that he had spent a lot of money to acquire the material necessary for the reproduction of the ordinances from the two former privilege holders, Josse Lambrechts and Victor de Dayn. ${ }^{61}$ On 23 Augustus 1577, the privilege for printing currency edicts was transferred to the Antwerp printer Guillaem van Parijs in agreement with Plantin. ${ }^{62} \mathrm{~A}$ few months before, the two men had printed a joint edition of a royal decree addressed to the Council of

54 On these indexes, see:Jesus M. De Bujanda (ed.), Index d'Anvers 1569, 1570, 1571 (Sherbrooke/ Geneva: Centre d'Études de la Renaissance/Droz, 1988).

55 Voet, The Golden Compasses, I, p. 72.

56 The petition is edited in: Correspondance de Christophe Plantin, II, pp. 247-248, nr. 247.

57 For the different editions, see: $P P$, nr. 1970-1975.

58 The original reads: "om temogen alleene drucken tgene dat der munte aengaert". See Van den Branden, 'Drukoctrooien', p. 59, nr. 321.

59 Rouzet, Dictionnaires des imprimeurs, pp. 108-109.

6o Van den Branden, 'Drukoctrooien', p. 39, nr. 183.

61 The original text reads: "à gros fraiz et dépens recouvert a acheté les formes figures et patrons de plusieurs espèces dor et dargent de divers coings et aultres vieus cles et instrumens dont feuz maistres Josse Lambrechts et victor de dayn" (АRB, СРE, 1276, 4O; Auguste Voisin, Josse Lambert, imprimeur, graveur, poète et grammairien gantois du XVIe siècle (Ghent: L. Hebbelynck, 1842), p. 46. Hendrik I vanden Keer's father, Pieter vanden Keere, bought Josse Lambrechts' workshop and woodcuts, which he rented to Jan Cauweel until 1556, when Henri I vanden Keer began his activities (Rouzet, Dictionnaires des imprimeurs, p. 108).

62 The original reads: "om alleene te mogen drucken d'affeyten nopende de munte by consente en Inde plaeste van christoffel plantin". See Van den Branden, 'Drukoctrooien', p. 64, nr. 36o. 
Brabant regarding the rates of golden and silver coins in the Low Countries, for the period from 1 July until Christmas $1577 \cdot{ }^{63}$

\section{The Birth of the Dynastic Monopoly}

Michiel van Hamont died on the night of October 24 to 25,1585 . He had no children. Three printers immediately applied for his lucrative position of official court printer: Jan I Mommaert, from Brussels, Guillaem van Parijs, from Antwerp, and Rutger Velpius, from Louvain. ${ }^{64}$ Jan I Mommaert's hopes of obtaining this position rested on his close friendship with Michiel van Hamont (who had notably served as a witness at his wedding). ${ }^{65}$ In his petition, he argued that he had always remained a Roman Catholic and had gone to Salamanca to join the King's party. ${ }^{66}$ For his part, Guillaem van Parijs insisted on his orthodoxy, specifying that he had never printed any banned books or books offending the King and had not taken part in the troubles that shook Antwerp. ${ }^{67}$

One printer, however, had even better claim to prove he was a loyal servant of the crown: Rutger Velpius. Velpius' close ties with the authorities are undoubtedly the reason for his designation as printer of his Majesty. By 1578, he had

63 The decree was printed in Dutch and French: Philip II, Placcart sur le faict et tollerance du pris et cours de la monnoye d'or et d'argent és pays de pardeça / Placcaet op tstuck ende tollerancie vanden prijs ende loop vande goude ende silvere munte, inde landen van herwertsovere (Antwerp: Christophe Plantin and Guillaem van Parijs, 1577), PP nr. 2015-2016; USTC 80847,412694 .

64 Only the petitions of Mommaert and van Parijs are still kept: ARB, CPE, 1276, 9. On Mommaert, see: Rouzet, Dictionnaires des imprimeurs, pp. 152-153; César Manrique Figueora, 'Los impresores bruselenses y su producción dirigida al mercado hispano, siglos XVI-XVII. El caso de la imprenta del Águila de Oro de Rutger Velpius, Hubert Anthoine-Velpius y la imprenta de los Mommaert', Erebea. Revista de Humanidades y Ciencias Sociales, 2 (2012), pp. 205-226.

65 Brussels, Archives of the City, Our Lady of the Chapel, Parish registers, Marriage records, 1575-1598, fol. 3or.

66 ARB, CPE, 1276, 9: "Tousiours maintenu en la religion Catholicque romaine, et suyvi le party de votre majeste en espaigne en votre ville de Salamanca".

67 ARB, СРE, 1276, 9: "Sans avoir Imprimer quelque livres defendu ou aultre chose quelconque contre sa Majeste ... et quil est toujiours demoure catholique nonobstant les troubles en Icelle ville nagueres advenues". Jasper van der Steen has shown that local officials also used to claim their loyal background to the King or to the Church as arguments in their petition to obtain a noble title or an appointment. See: Jasper Van Der Steen, Memory Wars in the Low Countries, 1566-1700 (Leiden/Boston: Brill, 2015), pp. 118-119. 
already received a monopoly on all placards from the Council of Brabant. ${ }^{68}$ At this time, Brussels was ruled by hardline Calvinists, which meant that Hamont was no longer able to print Habsburg ordinances. ${ }^{69}$ In May 1580, Alexander Farnese, Governor of the Spanish Low Countries, moved his court to Mons, in Hainaut. The relatively small city became the seat of government, which led to an urgent need for a printer to publish royal decrees. The town council managed to attract Rutger Velpius from Louvain by offering him a significant amount of money and a house near the market place to establish his venture. ${ }^{70}$ Velpius set up Mons' first printing press, which was entirely dedicated to the Habsburg Catholic cause. ${ }^{71}$ When Farnese moved to Brussels, after defeating the Calvinists on 10 March 1585, Velpius followed him. His appointment as official court printer was a reward for his fidelity and service. He established his printing house near the Palace of Coudenberg, the seat of the government.

Less than a year later, in November, Rutger Velpius together with Guillaem van Parijs were granted the privilege to reproduce all currency edicts promulgated by the crown. At the same time, Guillaem van Parijs obtained the exclusive right to reproduce 'all the booklets with woodcuts. ${ }^{2}$ Directly afterwards, Rutger Velpius and Guillaem van Parijs published - in French and in Dutch - a joint edition of the currency edict promulgated in Antwerp on 10 October 1585 . This document was issued to regulate the currency situation after the period of troubles (1577-1584) ${ }^{73}$ Guillaem van Parijs died a few months later in 1586.

68 Van den Branden, 'Drukoctrooien', p. 7o, nr. 399. On Velpius, see: Rouzet, Dictionnaires des imprimeurs, pp. 230-232; Manrique Figueora, 'Los impresores bruselenses', pp. 205-226; Pierre Delsaerdt and Yann Sordet (eds.), Lectures princières et commerce du livre. La bibliothèque de Charles III de Crö̈ et sa mise en vente (2 vols., Paris: Édition des Cendres, 2017).

69 On the Calvinist regime in Brussels - surprisingly little studied, compared to other towns like Ghent of Antwerp -, see: Olivier Cammaert, 'L'iconoclasme sous la République calviniste à Bruxelles', in Monique Weis (ed.), Des villes en révolte. Les 'Républiques urbaines' aux Pays-Bas et en France pendant la deuxième moitié du XVI e siècle (Turnhout: Brepols, 2010), pp. 47-52.

$70 \quad$ Christine Piérard and Pierre Ruelle, Les premiers livres imprimés à Mons: fac-similés de la 'Kakogeitnia' de Libert Houthem et du 'Renart decouvert' attribué à Jean Richardot, sortis des presses de Rutger Velpius, en 1580 (Mons: Société des bibliophiles belges, 1966); Afonso, 'L'imprimé officiel', p. 56.

71 The catalogue of Velpius' Mons press includes the official ban of outlawry issued by Philip II against William I, Prince of Orange, printed in 158 o by Velpius: Sommaire et substance du ban et proscription contre Guillaume de Nassau, prince d'Oranges, USTC 13596.

72 The original reads: "imprimer les livrets de monnoyes qui se feront avec les figures". See ARB, CPE, Private Council, 1276, 52; Van den Branden, 'Drukoctrooien', p. 71, nr. 402.

73 Philip II, Ordonnance et placcart sur le faict de la monnoye, ayant cours es pays de pardeça (Antwerp: Guillaem van Parijs and Rutger Velpius, [1585]), в в IV 543 O 175, UstC 80855; Philip II, Ordonnancie ende placcaet op t'feyt van der munte loop hebbende inde landen van herwaetsover (Brussels: Rutgerus Velpius and Guillaem van Parijs, 1585), UsTC 414846. 
His widow, Mechtelt Van den Wouwere, recovered his privilege and continued collaboration with Velpius. ${ }^{74}$ Together, they printed the extension of the previous ordonnance, proclaimed on 9 January $1587{ }^{75}$ In 1595 , Mechtelt van den Wouwere sold her venture to the Antwerp printer Hieronymus Verdussen, who had received his first octroi in $1589 .{ }^{76}$

Rutger Velpius and Hieronymus Verdussen founded two dynasties of printers who succeeded in turning the printing of official acts into a family monopoly. The two men and their successors requested the renewal of their status as official printers at least every ten years. Rutger Rescius and his son-in-law Hubert I Anthoine worked together from 1601 onwards. They received an extension of their grant for a period of 10 years on 17 August $1609 .{ }^{77}$ Rutger Rescius died around 1614-1615. Hubert I Anthoine succeeded him and asked to renew his grant on 9 August $1625 .{ }^{78}$ On 7 November 1634, Hubert II Anthoine obtained the right to print, for a period of ten years, all the edicts, statutes and regulations issued by the court, as his predecessors had been doing for sixty years. ${ }^{79}$ This privilege was accorded for another ten-year term on 9 May 1645 , on 9 February 1658 , and again on 27 March $1666 .{ }^{80}$ After the death of Hubert II Anthoine at the end of October 1670, his son Marcel Anthoine-Velpius obtained

74 Rouzet, Dictionnaires des imprimeurs, p. 168.

75 Philip II, Ordinantie ende placcaetnopende tfeyt vander munten (Antwerp: widow Guillaem van Parijs and Rutger Velpius, 1587), в в IV 543 O 182, not recorded in UsTC; Ordinantie ende placcaet nopende tfeyt vander munten (Antwerp: widow Guillaem van Parijs, 1587), USTC 413776; Ordinantie ende placcaet nopende tfeyt vander munten (Brussels: Rutgerus Velpius, 1587), USTC 413779.

${ }_{76}$ Prosper Verheyden, 'Drukkersoctrooien in de $16^{\mathrm{e}}$ eeuw', Tijdschrift voor Boek - en Bibliotheekwezen, 8 (1910), p. 225, nr. 162. On Verdussen, see: Rouzet, Dictionnaires des imprimeurs, pp. 233-234; Stijn van Rossem, 'The Bookshop of the Counter-Reformation revisited: the Verdussen Company and the Trade in Catholic Publications, Antwerp, 15851648', Quaerendo, 38 (2008), pp. 306-321 and Stijn van Rossem, Het gevecht met de boeken. De uitgeversstrategieën van de familie Verdussen [Antwerpen 1589-1689] (University of Antwerp, Unpublished PhD dissertation, 2014).

77 ARB, CPE, 1276, 134. Micheline Soenen made a mistake in her inventory of the archives of the Spanish Private Council. She erroneously thought that this privilege was granted for 6 years: Inventaire analytique des documents relatifs à l'impression et au commerce des livres (1546-1702) contenus dans les cartons 1276 à 1280 du Conseil Privé espagnol (Brussels: State Archives of Belgium, 1983), p. 24, nr. 134.

78 ARB, CPE, 1277, 93. On Hubert I Anthoine and his family, see: Paul E. Claessens, 'Deux familles d'imprimeurs brabançons: les Velpius et les Anthoine-Velpius (1542 à 1689)', Brabantica, 2 (1957), pp. 333-347; Rouzet, Dictionnaire des imprimeurs, pp. 1-2; Renaud Adam, 'Une enquête dans les milieux du livres à Bruxelles en avril 1689', Histoire et civilisation du livre. Revue internationale, 14 (2018), pp. 53-64.

79 ARB, CPE, 1278, 77 .

8 O ARB, CPE, 1278,$77 ; 1279,94 ; 1280,36$. 
the same privilege for ten years. ${ }^{81} \mathrm{He}$ died seven years later without heir, and was buried on 30 March $1677 .{ }^{82}$ Four days later, on 4 June 1677 , Jean-Théodore Anthoine-Velpius addressed a petition to the Privy Council asking to succeed his brother. ${ }^{83}$ On 16 May 1689, following the death of Jean-Théodore Anthoine-Velpius, the position of official court printer passed to Eugène-Henry Frickx. ${ }^{84}$ The situation was the same for the Verdussen family that had systematically sought to renew its privileges. ${ }^{85}$ In the mid-seventeenth century, they also obtained an official monopoly for printing almanacs, forbidding anyone to print these ephemera in the Low Countries. ${ }^{86}$

The zeal with which these two families ensured that their privileges were renewed shows how much these monopolies brought them secure and regular incomes. They also had the advantage of working for only one client. They were, therefore, less affected by all the problems related to the normal trade of books (storing books, sending books to booksellers, dealing with colleagues at book fairs, etc.).

It would appear that the government would pay the wage in monthly instalments. The archives of the Council of Finance keep records of payments of 302 guilders and 12 stuivers to Hubert II Anthoine-Velpius on 26 March 1643 and on 21 April 1643; which represents an annual payment of around 3600 guilders and 150 stuivers. ${ }^{87}$ Sometimes remuneration was delayed, as the state was not always very prompt to pay its debts. For example, Hubert II

81 Brussels, Archives of the City, St Gudula, Parish registers, Death certificates, 1669-1683, fol. 66v; ARB, Spanish Private Council, 128o, 36 .

82 Brussels, Archives of the City, St Gudula, Parish registers, Death certificates, fol. 243r.

83 ARB CPE, 1280, 36 .

84 ARB, CPE, 1280, 10. On this printer and his family, see: Paul E. Claessens, 'Deux familles d'imprimeurs brabançons: les Mommaert et les Fricx (1585 à 1777)', in Brabantica, 3 (1958), pp. 217-219; Claude Sorgeloos, 'Les réseaux commerciaux de Guillaume Fricx, imprimeur et libraire à Bruxelles (1705-08)', in Adam (ed.) Urban Networks and the Printing, pp. 1-37; Claude Sorgeloos, 'Travaux et clients de Guillaume Fricx, imprimeur et libraire à Bruxelles (1705-1708)', in Monte Artium. Journal of the Royal Library of Belgium, 6 (2013), pp. 141-166.

85 ARB, CPE, 1276, 118; 1277, 118; Van Rossem, Het gevecht met de boeken, pp. 69-79.

86 Stijn Van Rossem, 'The Struggle for Domination of the Almanac Market: Antwerp, 162642', The Papers of the Bibliographical Society of America, 106 (2012), pp. 63-99.

87 ARB, Council of Finance, 268. I would like to thank Nicolas Simon (Royal Academy of Belgium - Catholic University of Louvain) for drawing my attention to these archives. By way of comparison, in 1650, the amount of annual wages for an enterprise of the size of Plantin-Moretus amounted to 17.792 guilders; the equivalent of 9 kilos of gold. See Charles Verlinden (ed.) Documents pour l'histoire des prix et salaires en Flandre et en Brabant (3 vols., Bruges: De Tempel, 1959-1972), II, p. 106o. 
Anthoine-Velpius wrote in 166o complaining that his salary had not been paid between 18 October 1659 and 1 July $1660 .{ }^{88}$

The possession of monopolies ensured the economic viability of these ventures. All petitions made by these families refer to the investments they had to make to obtain the right of printing royal ordinances and, implicitly, the need for them to obtain the grant to get a return on these investments. Hieronymus Verdussen II mentioned in his petition of 31 August 1643 that he had already gone to great expense, and he still had to pay every day to cut engravings and woodcuts. ${ }^{89}$ Hubert Anthoine-Velpius II asked in 166 o for an increase of his salary because of the increase in the price of paper and the cost of his employees' wages. ${ }^{90}$ In another example, when Marcel Anthoine-Velpius died unexpectedly, the family business almost collapsed. The petition of 4 June 1677 sent to the Privy Council explained that if they lost the monopoly on royal edicts:

this poor family would be completely ruined, not knowing what to do with its handpresses and all its utensils, most of which are used only to print ordinances, tariffs and other items from His Majesty. These cost their ancestors so much money, forcing them to commit and sell everything they had to buy the house they occupy near the court so that they could print the hasty things that hurry there, having since had to mortgage their house for more than four thousand guilders in order to continue the service of His Majesty. ${ }^{91}$

88 ARB, Council of Finance, 268. The situation seems to be the same in the Dutch Republic. The official printer of the State General and of the State of Holland, Hillebrant II van Wouw, was also facing non-payment of his wage. This is why he resigned his office in 1669 . He thought that he would be richer if the States would pay their debts. On this case, see Pettegree and der Weduwen, Bookshop of the World, p. 195.

89 ARB, CPE , 1278, 118: "Es grandz fraiz ... qu'il a fait et faict encore journellement a faire tailler les figures es monnoys".

$90 \quad \mathrm{ARB}$, Council of Finance, 268: "demandé davantage que ses predecesseurs en office, nonobstant que les papier et le travail est en ce temps beaucoup plus cher qu'il n'estoit il y a cincquante et plus d'années".

$91 \mathrm{ARB}, \mathrm{CPE}, 128 \mathrm{O}, 36:$ "Cette pauvre famille seroit entierement ruinée, ne sachant que faire de l'Imprimerie ni de tous les ustensils d'Icelle qui ne servent la plupart que pour Imprimer des Placcarts, tariffs et aultres pieces touchant le service de sa Majesté qui ont cousté tant d'argent a leurs ancestres, et que mesmes Ils ont estés obligés de s'engager et a vendre tou ce qu'ils avoient pour achapter la maison qu'ils occupent pres de la cour affin d'estre plus a la main pour Imprimer les choses pressées qui s'y depeschent, ayant depuis du charger laditte maison de plus de quatre mil florins afin de pouvoir continuer le service de sa Majesté". 
This petition also testifies that the members of these families carefully preserved privileges granted by the authorities. Copies of all the previous petitions made by the Velpius-Anthoines were attached to this petition. There were also exceptions to the monopolies obtained by this family. For example, on 12 December 1587 , Charles Michel received the authorisation to print all edicts promulgated in Mons by order of the King. ${ }^{92}$ The printer Jan Scheffer II obtained the same privilege for his own town, 's Hertogenbosch, on 21 April 158 o, and 4 May 1596.93

Despite the prohibitions, counterfeits appeared on the market. In response, wronged typographers did not hesitate to file complaints with the Privy Council. Between 19 December 1613 and 28 March 1614, the firm Velpius-Anthoine sued Jan Vanden Steen III, from Ghent, because he had printed an ordinance regulating hunting, issued on 13 Augustus $1613 .{ }^{94}$ Vanden Steen argued that, as official printer of the Council of Flanders, he had the authorisation to reprint the ordinance. The Privy Council rejected Vanden Steen's argument. ${ }^{95}$ Thirty years later, in 1640, Hubert Anthoine-Velpius II filed a complaint against François de Waudré, from Mons, because he had just published an edict on the exemptions for elite heavy cavalry ${ }^{96}$ François de Waudré exposed himself not only to the confiscation of the copies, but also to a fine of three carolus guilders for each copy printed or sold. The fine was divided between the state and the plaintiff. Printers were therefore the real "drivers" of the implementation of the law and the suppression of this type of fraud. ${ }^{97}$

Other families than the Velpius-Anthoines and the Verdussens obtained monopolies from civil and religious authorities: the Vanden Steens, from Ghent, were official printers of the Council of Flanders till the mid-seventeenth

92 ARB, CPE, 1276, 61.

93 ARB, CPE, 1276, 44, 91.

94 Albert and Isabella, Translaet van het edict ende ordinantie vande eetzhertoghen, $\mathrm{Op}$ het stuck vande jachte (Ghent: Jan vanden Steene III, 1613), UsTC 1024659; Albert and Isabella, Edict et ordonnance sur le fait de la chasse/Translaet van het edict ende ordonnantie vande Erts-hertoghen op het stuck van de jachte (Brussels: Rutger Velpius and Hubert Anthoine-Velpius I, 1613), USTC 1004499, 1514847.

95 ARB, CPE, 1276, 353 .

$96 \mathrm{ARB}, \mathrm{CPE}, 1278,217$. See also: Afonso, Imprimeurs, société et réseaux, pp. 152-153. References of the edict: Placcaert ons heeren des conincx. Nopende de exemptien ende vrydommen vande benden ende compaignien van ordonnantien / Placcart sur les exemptions et franchises des Bendes et Compaignies d'Ordonnances (Brussels, Hubert Anthoine-Velpius II, 1640), USTC 1511645,1511648 . The Waudré's impression is not recorded in USTC or in Hippolyte Rousselle's Annales de l'imprimerie à Mons, depuis 1580 jusqu'à nos jours. Bibliographie montoise (Mons: Masquillier \& Lamir, 1858).

97 Hieronymus Verdussens was also involved in a trial for illegal competition (23 June 1618). See: ARB, CPE, 1277, 227. 
century; the Plantin-Moretusses enjoyed a monopoly on several liturgical books until the end of the Ancien Regime; the Mommaerts were official printer of the State of Brabant, etc. ${ }^{98}$ The different levels of power (municipality, provincial councils, etc.) have therefore provided many printers with the opportunity to secure permanent resources. It is easy to understand why printers have endeavoured to obtain exclusivity for printing to these types of publication.

\section{Conclusion}

The introduction of the printing art in the Low Countries did not provoke an immediate revolution in the regulations of the book trade and in the promulgation of laws. The central authorities began to use this medium to spread their ordinances and edicts at the end of the fifteenth century. During the reign of Charles $\mathrm{V}$, the government became fully aware of the benefits of printing legislation. This period corresponds to a strengthening of central authorities and an increase in legislation. At that time, the Council of Brabant and, later, the Privy Council began granting sole rights of printing ordinances and other documents issued by these bodies. The protection afforded to selected printers also made it possible to strengthen control over their activities. Privileges were backed by sanctions so that they could be effective. Punishment for infringements usually consisted of confiscations of the pirated copies with an addition of a fine for each copy illegally printed. At the beginning, monopolies were normally privileges of very limited duration. Circumstances changed under Philipp II with the creation of the titles of official court printer and official currency edict printer. Exclusive rights to reproduce legal acts were given to this office holder for longer periods. It was a very lucrative office because it provided its holder with secure financial resources. In order to safeguard the existence and the prosperity of their venture, some printers implemented protective strategies to maintain these privileges within their family. The Velpius-Anthoines in Brussels managed to transform their status as official court printer into a dynastic monopoly, and the Verdussens did the same in Antwerp for currency edicts. Beyond financial capital, the possession of these privileges conferred significant social and symbolic capital. They were rewarded for the quality of their work and appeared to be close to the government.

98 Voet, The Golden Compasses, I, p. 266; Micheline Soenen, 'Impression et commerce des livres aux XVI ${ }^{\mathrm{e}}$ et XVII ${ }^{\mathrm{e}}$ siècle. Réflexions en marge d'un inventaire des cartons du Conseil Privé espagnol', Archives et Bibliothèques de Belgique, $5^{6}$ (1985), pp. 83-84. 
The analysis of relations between printers and authorities - be they central or local - certainly deserves further study. Other investigations should be conducted on a broader scale in a more systematic manner, especially from the point of view of bibliographical analysis. The market for official prints deserves to be better known. Indeed, political and religious powers contributed to stimulate typographical activities and to modify the editorial landscape of the Low Countries, especially in the French-speaking cities with a restricted commercial outlet. ${ }^{99}$ Studying strategies developed by printers to obtain and maintain monopolies on official printing would make a significant contribution to our understanding of social practices around lobbying and petitioning in early modern Europe. One should also look at the business horizons of these official documents: who is the audience? what was the use of these documents? is the production homogeneous in its typographical form and in time? A question also remains: under what conditions did these documents reach us? Knowledge of early modern legislation through the study of print is clearly a field of research that is only in its infancy and deserves further investigation.

99 Afonso, 'L'imprimé officiel', pp. 53-76. 